\title{
Effect of variety and method of USG placement on the yield performance of transplanted aman rice
}

\author{
N. Mohammad*, N. Islam, A. T. M. Ziauddin ${ }^{1}$ and M. M. Hossain \\ Department of Agronomy, Bangladesh Agricultural University, Mymensingh-2200 and ${ }^{1}$ Department of Farm Power \\ and Machinery, Bangladesh Agricultural University, Mymensingh-2200, Bangladesh, *E-mail : nmsoton@gamil.com
}

\begin{abstract}
A field experiment was conducted at the Agronomy Field Laboratory, Bangladesh Agricultural University, Mymensingh during the period from July to December 2011 to evaluate the effect of variety and placement method of urea super granule (USG) on the yield performance of $T$. aman rice varieties. The experiment consisted of three aman rice varieties viz., Pajam, BR11, BRRI dhan40 and four placement methods viz., broadcasting method of prilled urea (PU), USG placement by hand, by BAU USG applicator and by BARI USG applicator. The experiment was laid out in a randomized complete block design with four replications. The highest value of grain yield (5.13 t/ha), straw yield (5.90 t/ha) and biological yield (11.04 t/ha) were found in BR11. On the other hand, the lowest grain yield (3.54 t/ha) was produced in variety Pajam. The highest grain and straw yields (5.13 and 5.21 t/ha, respectively) were obtained from the hand placement method of USG. Regarding the interaction of variety and USG placement method, BR11with hand placement method appeared as the best method among others.
\end{abstract}

Keywords: T. aman rice, Urea super granule (USG), USG applicator, Prilled urea, Yield

\section{Introduction}

Rice (Oryza sativa L.) is one of the most important cereals in the world. It is the staple food for more than half of the world population and grows in more than 100 countries. China, India, Indonesia, Bangladesh, Thailand and Vietnam produce about $80 \%$ of the world rice. Among the leading rice growing countries of the world, Bangladesh ranks fourth in both rice area and production (BRRI, 2011). In Bangladesh rice accounts for $95 \%$ of the annual food grain production. It provides about $75 \%$ of the calories and $55 \%$ of the protein in the average daily diet of the people of the country (Bhuiyan et al., 1998). Bangladesh is an agro-based country and predominately rice based. Agriculture contributes about $19.95 \%$ of the gross domestic product (GDP) of the country (BBS, 2010). In the year 2010-11, the area and production of rice in the country were 11.28 million hectares and 31.31 million tons, respectively (BBS, 2010). Nitrogen is one of the essential plant nutrients which can augment the production of rice to a great extent. Application of urea-N plays a vital role in vegetative growth, development and yield of rice. The importance of the role of nitrogenous fertilizer in increasing rice yields has been widely recognized. But $\mathrm{N}$-use efficiency from urea fertilizer is very low and the recovery of $\mathrm{N}$ in wetland rice seldom exceeds 40\% (De Datta and Buresh, 1989). Yearly requirement of urea in Bangladesh is 2.9 million tons (mt) of which $80 \%(2.3 \mathrm{mt})$ is used for rice alone. Urea is usually applied in prilled condition by hand. Its application efficiency is only 35 to $40 \%$. When it is applied in super granule form, its application efficiency is increased to 60 per cent. If all the urea could be applied in super granule form, then $1.15 \mathrm{mt}$ urea could be saved. In that case only $0.05 \mathrm{mt}$ urea needs to be imported (BADC, 2011).If urea is applied in super granule form, a huge amount of urea production could be reduced, which in turn would save a lot of natural gas. The saved natural gas could be used to generate electricity (Bowen et al., 2005). Usually USG is applied by hand, which is a very time consuming and laborious job. Yet many farmers in different parts of the country use this technology to get more yields with less fertilizer. Moreover, in this method, one top-dressing is required instead of two as required in prilled urea. International Fertilizer Development Corporation (IFDC) has been trying to popularize the USG technology in different countries for many years. They became successful to some extent. But due to lack of a good applicator, the technology could not be popularized to the desired level. Recently, the scientists of Farm Machinery Division of BARI have successfully developed a hand operated USG applicator. This applicator applies USG at 6 to $7 \mathrm{~cm}$ depth below the soil surface in the middle of four bunches of rice seedlings. When USG is applied by hand, 28 hours are required per hectare, whereas only 10 hours are required by the applicator (BARI, 2008). The biggest advantage of the applicator is the reduction of drudgery. In turn urea 
requirement and production cost will be reduced and rice production will be increased. From the above discussion, it is clear that USG is an important source of nitrogen and has great impact for increasing the nitrogen use efficiency, yield of rice and its application method is also an important factor contributing to total cost of production. It is known that the response of crops to nitrogen varies due to variety. So it is essential to investigate the response of $T$. aman rice varieties to different doses of USG. In view of the above discussion the present study was designed and carried out to evaluate the effect of USG compared to prilled urea as a source of nitrogen on the yield of different $T$. aman rice varieties and to determine the suitability of hand placement of USG against two mechanical devices of USG application.

\section{Materials and Methods}

The experiment was carried out at the Agronomy Field Laboratory of the Bangladesh Agricultural University, Mymensingh during the period from July to December 2011. The soil of the experimental field lies in agro-ecological region of Old Brahmaputra Floodplain (AEZ 9). It belongs to the Sonatola series of non-calcareous dark grey floodplain type. It was a two factor experiment consisting three aman rice varieties viz., Pajam, BR11, BRRI dhan40 and four placement method viz., broadcasting method of prilled urea, USG placement by hand, by BAU USG applicator and by BARI USG applicator. Randomize complete block design (RCBD) was laid out with four replications. Treatments were assigned randomly in the $48(3 \times 4 \times 4)$ unit plots. Spaces between blocks and unit plots were $0.75 \mathrm{~m}$ and $0.50 \mathrm{~m}$, respectively. The size of unit plot was $20 \mathrm{~m}^{2}(8.0 \mathrm{~m} \times 2.5 \mathrm{~m})$. One month old seedlings were transplanted on 10 August2011 maintaining no spacing for broadcasting method of prilled urea, row and hill spacing of (25 $\mathrm{cm} \times 15 \mathrm{~cm})$ for hand placement of USG and spacing $(20 \mathrm{~cm} \times 20 \mathrm{~cm})$ for both machine placement of USG. Intercultural operations were done in order to ensure and maintain the normal growth of the crop as and when necessary. When $90 \%$ of grain became golden yellow in color, five hills (excluding border hills) were randomly selected from each unit plot for recording data on different agronomic crop characters. Grain and straw yields were recorded from whole area in each unit plot. The collected data were analyzed statistically following the Analysis of Variance (ANOVA) technique and the significance of the mean differences were adjudged by Duncan's Multiple Range Test (DMRT) (Gomez and Gomez,1984) using a statistical computer package program MSTAT-C.

\section{Results and Discussion}

\section{Effect of variety}

Effect of variety on yield and yield contributing components of rice have been presented in Table 1. BR11 produced the tallest plant $(139.20 \mathrm{~cm})$ while the shortest plant $(109.8 \mathrm{~cm})$ was obtained from Pajam and the height of BRRI dhan40 was $(131.00 \mathrm{~cm})$. These results were consistent to those of Om et al. (1998), Khisha (2002) and Rahman (2003). The highest number of total tillers per hill was observed in BR11 (16.60) and the lowest one (10.30) was counted in Pajam. Results indicated that the highest number of effective tillers per hill was produced by BR11 (12.4) and the lowest one (7.4) was produced by Pajam. The probable reason of the differences in producing the effective tillers per hillis the genetic make-up of the variety which is primarily influenced by heredity. This finding corroborates with those reported by BINA (1998), Om et al. (1998) and Bhowmick and Nayak (2000). The result showed that BR11 produced the longest panicle length $(25.61 \mathrm{~cm})$. Pajam produced the shortest panicle length $(23.38 \mathrm{~cm})$. The highest number of grains panicle ${ }^{-1}(135.1)$ was found from BR11 the lowest $v$ results aralue was observed from Pajam (96.6). These result are consisted with Srivastava and Thipathi (1998), Bhowmick and Nayak (2000), Singh and Gangwer (1989). Values for 1000-grain weight ranged from $26.16 \mathrm{~g}$ to $20.27 \mathrm{~g}$. It can be seen that BR11produced the highest $(26.16 \mathrm{~g})$ 1000-grain weight. The lowest $(20.27 \mathrm{~g})$ value was obtained from Pajam. These results are in agreement with Samsuddin et al. (1988) and Chowdhury et al. (1993) who reported variation in 1000-grain weight among the varieties. BR11gave the highest grain yield (5.13 t/ha). Grain yield from BRRI dhan40 was recorded4.52 t/ha. Pajam produced the lowest grain yield (3.54 t/ha). Varietal differences regarding grain yield was also reported by Patel (2000) and Khisha (2002). This might be due to the genetical causes of the varieties. The highest straw yield (5.90 t/ha) was produced by BR11 while the lowest straw yield (3.99 t/ha) was recorded from Pajam. These results are in 
conformity with those obtained by Chowdhury et al. (1993) and Patel (2000). It is found that the highest biological yield (11.04 t/ha) due to highest grain and straw yield was recorded from BR11. BRRI dhan40 produced the second highest $(9.03 \mathrm{t} / \mathrm{ha})$ biological yield. The lowest biological yield $(7.53 \mathrm{t} / \mathrm{ha})$ was obtained from Pajam. The highest harvest index (50.06\%) was recorded from BRRI dhan40. The lowest one $(46.94 \%)$ was obtained from Pajam. Varietal effect on the grain, straw yield and other plant parameters in our study revealed that among the four varieties used BR11 yielded the highest values for grain and straw yield including almost all other plant characters. This happened might be due to the genetical variation for yield potentials among the varieties.

Table 1. Effect of variety on crop characters and yield of $T$. aman rice varieties

\begin{tabular}{|c|c|c|c|c|c|c|c|c|c|c|c|c|}
\hline Variety & $\begin{array}{l}\text { Plant } \\
\text { height } \\
(\mathrm{cm})\end{array}$ & $\begin{array}{c}\text { Total } \\
\text { tillers hill -1 } \\
\text { (no.) }\end{array}$ & $\begin{array}{l}\text { Effective } \\
\text { tillers hill-1 } \\
\text { (no.) }\end{array}$ & $\begin{array}{c}\text { Non } \\
\text { effective } \\
\text { tillers hill-1 } \\
\text { (no.) }\end{array}$ & $\begin{array}{l}\text { Panicle } \\
\text { length } \\
(\mathrm{cm})\end{array}$ & $\begin{array}{l}\text { Grain } \\
\text { panicle-1 } \\
\text { (no.) }\end{array}$ & $\begin{array}{c}\text { Sterile } \\
\text { spikelet } \\
\text { panicle-1 }^{-1} \\
\text { (no.) } \\
\end{array}$ & $\begin{array}{c}1000 \\
\text { grain } \\
\text { weight } \\
(\mathrm{g})\end{array}$ & $\begin{array}{l}\text { Grain } \\
\text { yield } \\
\text { (t/ha) }\end{array}$ & $\begin{array}{l}\text { Straw } \\
\text { yield } \\
\text { (t/ha) }\end{array}$ & $\begin{array}{c}\text { Biological } \\
\text { yield } \\
\text { (t/ha) }\end{array}$ & $\mathrm{HI}(\%)$ \\
\hline BR11 & $139.2 a$ & $16.60 \mathrm{a}$ & $12.4 a$ & $4.10 a$ & $25.61 a$ & $135.1 \mathrm{a}$ & $27.6 a$ & $26.16 a$ & $5.13 a$ & $5.90 a$ & $11.04 a$ & $45.90 \mathrm{~b}$ \\
\hline BRRI dhan 40 & $131.0 \mathrm{~b}$ & $10.8 \mathrm{~b}$ & $8.20 \mathrm{~b}$ & $2.7 \mathrm{~b}$ & $24.15 b$ & $133.8 \mathrm{a}$ & $21.3 b$ & $25.22 b$ & $4.52 \mathrm{~b}$ & $4.51 \mathrm{~b}$ & $9.03 b$ & $50.06 a$ \\
\hline Pajam & $109.8 \mathrm{c}$ & $10.3 c$ & $7.4 \mathrm{c}$ & $2.7 \mathrm{~b}$ & $23.38 \mathrm{c}$ & $96.6 \mathrm{~b}$ & $14.7 \mathrm{c}$ & $20.27 \mathrm{c}$ & $3.54 \mathrm{c}$ & $3.99 \mathrm{c}$ & $7.53 c$ & $46.94 \mathrm{~b}$ \\
\hline$s \bar{x}$ & 0.9981 & 0.1 & 0.14 & 0.04 & 0.19 & 1.11 & 0.21 & 0.22 & 0.05 & 0.08 & 0.10 & 0.52 \\
\hline $\mathrm{LSD}_{0.05}$ & 2.872 & 0.42 & 0.40 & 0.12 & 0.55 & 3.21 & 0.62 & 0.64 & 0.16 & 0.23 & 0.30 & 1.49 \\
\hline $\begin{array}{c}\text { Level of } \\
\text { significance }\end{array}$ & ** & ** & ** & ** & ** & ** & ** & ** & ** & ** & ** & ** \\
\hline CV\% & 3.15 & 4.67 & 6.04 & 5.57 & 3.15 & 3.66 & 4.10 & 3.73 & 5.16 & 6.70 & 4.58 & 4.37 \\
\hline
\end{tabular}

In a column figures with same letters do not differ significantly whereas figures with dissimilar letters differ significantly (as per

DMRT).

${ }^{* *}=$ Significance at $1 \%$ level of probability

${ }^{*}=$ Significance at $5 \%$ level of probability

\section{Effect of placement method of urea super granule (USG)}

Influence of placement methods of urea super granule on yield and yield contributing components of rice have been presented in Table 2. Plant height showed a non-significant response to the placement method of USG. The highest number of total tillers hill ${ }^{-1}$ (13.68) was observed when USG applied by hand and the lowest one (12.31) was recorded when USG was applied by BAU USG applicator. USG placed by hand performed better (10.1) in respect of producing effective tillers hill ${ }^{-1}$ which is statistically similar to the USG applied by BARI applicator (9.7). The lowest number of effective fillers hill ${ }^{-1}(8.3)$ was obtained from PU by broadcasting method. The highest number (3.6) of non-effective tillers per hill was produced when the crop was fertilized with USG that was placed by hand. The lowest number (2.8) of non-effective fillers hill ${ }^{-1}$ was found when USG applied by BARI USG applicator. The longest panicle $(25.38 \mathrm{~cm})$ was produced when USG was applied by hand and the shortest one $(22.86 \mathrm{~cm})$ was produced when fertilized with PU by broadcasting methodThe highest number of grains per panicle (137.7) was obtained from hand placement of USG and the lowest one (112.1) was recorded from PU with broadcasting method which was statistically similar to that of USG placement method by BAU applicator. The highest number of sterile spikelets per panicle (25.3) was recorded from hand placement method of USG. The lowest number of sterile spikelets (15.9) was found in PU placed by broadcasting method. USG placement method by BAU USG applicator and USG placement method by BARI USG applicator showed the number of sterile spikelets per panicle were (20.1) and (23.5), respectively. The placement method of US exerted non-significant response on 1000-grain weight (Table 2). The highest grain yield (5.13 t/ha) was found when USG applied by hand. The second highest grain yield (4.61 t/ha) was obtained from USG applied by BARI USG applicator which was statistically similar to USG applied by BAU USG applicator and the lowest yield (3.34 t/ha) obtained from PU applied by broadcasting method. It is evident from Table 2 that the highest straw yield $(5.21 \mathrm{t} / \mathrm{ha})$ was produced from hand placement of USG. The lowest straw yield (4.37 t/ha) was obtained from PU by broadcasting method. Yield from both machine placement of USG were statistically similar. The result showed that the biological yield was highest (10.35 t/ha) due to hand placement of USG. The lowest biological yield (7.71 t/ha) was recorded at broadcasting of PU. The highest harvest index $(49.51 \%)$ was recorded from hand placement of USG which was statistically similar to other two methods of USG placement by machine and the lowest one $(44.03 \%)$ was obtained from PU placed by broadcasting method. 
The used PU and USG exhibited their differences in all the parameters. The result showed that the broadcasting method of PU showed lowest performance than USG. It might be due to different losses of PU when applied by broadcasting method like evaporation, leaching loss, etc. but when urea applied in USG form it was possible to minimize the extra loss of urea. Among the placement method of USG, hand placement method of USG showed highest results. This result proved that hand placement method of USG was the best method on yield performance of $T$. aman rice. These might be happened due to uniform placement of urea in the root zone in case of USG applicator due to blocking problem in discharge pipe USG pillets were not placed uniformly.

Table 2. Effect of different placement methods of USG on crop characters and yield of $T$. aman rice varieties

\begin{tabular}{|c|c|c|c|c|c|c|c|c|c|c|c|c|}
\hline Variety & $\begin{array}{l}\text { Plant } \\
\text { height } \\
\text { (cm) }\end{array}$ & $\begin{array}{c}\text { Total } \\
\text { tillers hill -1 } \\
\text { (no.) }\end{array}$ & $\begin{array}{l}\text { Effective } \\
\text { tillers hill-1-1 } \\
\text { (no.) }\end{array}$ & $\begin{array}{c}\text { Non effective } \\
\text { tillers } \\
\text { hill-1 }^{-1} \text { (no.) }\end{array}$ & $\begin{array}{l}\text { Panicle } \\
\text { length } \\
(\mathrm{cm})\end{array}$ & $\begin{array}{l}\text { Grain } \\
\text { panicle-1 } \\
\text { (no.) }\end{array}$ & $\begin{array}{c}\text { Sterile } \\
\text { spikelet } \\
\text { panicle-1 } \\
\text { (no.) }\end{array}$ & $\begin{array}{l}1000 \text { grain } \\
\text { weight } \\
\text { (g) }\end{array}$ & $\begin{array}{l}\text { Grain } \\
\text { yield } \\
\text { (t/ha) }\end{array}$ & $\begin{array}{l}\text { Straw } \\
\text { yield } \\
\text { (t/ha) }\end{array}$ & $\begin{array}{c}\text { Biological } \\
\text { yield } \\
\text { (t/ha) }\end{array}$ & $\mathrm{HI}(\%)$ \\
\hline $\mathrm{T}_{1}$ & 124.7 & $11.3 \mathrm{~d}$ & $8.3 c$ & $2.9 \mathrm{c}$ & $22.86 \mathrm{c}$ & $112.1 \mathrm{c}$ & $15.9 \mathrm{~d}$ & $3.34 \mathrm{c}$ & $4.37 \mathrm{c}$ & 23.70 & $7.71 \mathrm{c}$ & $44.0 \mathrm{~b}$ \\
\hline$T_{2}$ & 128.8 & $13.6 \mathrm{a}$ & $10.1 \mathrm{a}$ & $3.6 \mathrm{a}$ & $25.38 \mathrm{a}$ & $137.7 \mathrm{a}$ & $25.3 a$ & $5.13 a$ & $5.21 \mathrm{a}$ & 24.09 & $10.35 \mathrm{a}$ & $49.5 a$ \\
\hline$T_{3}$ & 126.9 & $12.3 \mathrm{c}$ & $9.2 \mathrm{~b}$ & $2.8 \mathrm{c}$ & $24.44 b$ & $113.8 \mathrm{c}$ & $20.1 \mathrm{c}$ & $4.50 \mathrm{~b}$ & $4.80 \mathrm{~b}$ & 23.84 & $9.31 \mathrm{~b}$ & $48.1 a$ \\
\hline $\mathrm{T}_{4}$ & 126.4 & $13.0 \mathrm{~b}$ & $9.7 \mathrm{a}$ & $3.3 \mathrm{~b}$ & $24.83 a b$ & $123.9 b$ & $23.5 b$ & $4.61 b$ & $4.82 \mathrm{~b}$ & 23.89 & $9.43 b$ & $48.8 \mathrm{a}$ \\
\hline$s \bar{x}$ & - & 0.16 & 0.16 & 0.05 & 0.22 & 1.28 & 0.25 & 0.06 & 0.09 & - & 0.12 & 0.60 \\
\hline $\mathrm{LSD}_{0.05}$ & - & 0.48 & 0.46 & 0.14 & 0.63 & 3.70 & 0.72 & 0.18 & 0.26 & - & 0.35 & 1.73 \\
\hline $\begin{array}{c}\text { Level of } \\
\text { significanec }\end{array}$ & NS & ** & ** & ** & ** & ** & ** & ** & ** & NS & ** & ** \\
\hline CV\% & 3.15 & 4.67 & 6.04 & 5.57 & 3.15 & 3.66 & 4.10 & 5.16 & 6.70 & 3.73 & 4.58 & 4.37 \\
\hline
\end{tabular}

In a column figures with same letters letter do not differ significantly whereas figures with dissimilar letters differ significantly (as per DMRT). ${ }^{* *}=$ Significance at $1 \%$ level of probability, $\mathrm{T}_{1}=$ Traditional urea by broadcasting method, $\mathrm{T}_{2}=$ Hand placement method of USG, $T_{3}=$ BAU USG applicator method, $T_{4}=$ BARI USG applicator method

\section{Interaction effect of variety and placement method of urea super granule}

Interaction effect of variety and placement method of urea super granule on yield and yield contributing components of rice have been presented in Table 3. There was non-significant difference in plant height due to interaction of variety and placement method of USG. The longest plant $(140.6 \mathrm{~cm})$ was obtained due to the interaction of BR11 and hand placement of USG while the shortest plant $(109.3 \mathrm{~cm})$ was obtained due to the interaction of Pajam and BARI USG applicator. BR11 with hand placement of USG produced the highest number (18.1) of total tillers per hill. Pajam with broadcasting of PU produced the lowest number (9.4) of total tillers per hill Results from table 3 showed that the highest number of effective tillers hill ${ }^{-1}$ (13.60) was counted from the treatment combination of BR11 and hand placement of USG and the lowest one (6.8) was produced by the interaction between Pajam and broadcasting method of PU. The maximum number of non-effective tillers per hill (4.4) was produced by BR11 with USG placement by hand and the minimum one (2.20) was also counted in BRRI dhan40 growing with USG placed by BAU applicator. The longest panicle $(26.26 \mathrm{~cm})$ was produced by BR11 with hand placement of USG. The shortest panicle $(21.77 \mathrm{~cm})$ was produced by Pajam with broadcasting method of PU. The result showed that interaction between BR11 and hand placement of USG was found to be the best in respect of number of grains per panicle (156.2), on the other hand the lowest number of grains per panicle (86.92) was obtained from the interaction between Pajam and PU by broadcasting method. The highest number of sterile spikelets panicle ${ }^{-1}(34.6)$ was found from BR11 with USG placement method by hand. The lowest number of unfilled grains per panicle (10.1) was recorded from Pajam and broadcasting method of PU. The heaviest 1000 -grain weight $(26.37 \mathrm{~g})$ was obtained from the combination of BR11 with hand placement of USG. The lowest 1000-grain weight $(20.10 \mathrm{~g})$ was obtained from Pajam with traditional placement by broadcasting. It was observed that the highest grain yield $(6.05 \mathrm{t} / \mathrm{ha})$ was recorded from the treatment combination of BR11 with hand placement of USG and the lowest one (3.20 $\mathrm{t} / \mathrm{ha}$ ) was found from the interaction of Pajam with broadcasting method of PU. The highest straw yield $(6.0 \mathrm{t} / \mathrm{ha}$ ) was obtained from the combination of BR11 with hand placement of USG which is statistically similar with the combination Pajam and placement method of USG by BARI and BAU USG applicator. The highest biological yield (12.1 t/ha) obtained from the combination of BR11 and hand placement of USG and the lowest one (7.02t/ha) from BRRIdhan40 and broadcasting method of PU. The highest harvest index (50.24 \%) was recorded from BR11 with hand placement of USG. The lowest one (36.37 $\%)$ was obtained from BR11 broadcasting method of PU. 
Table 3. Interaction effect of variety and placement methods of USG on crop characters and yield of $T$. aman rice

\begin{tabular}{|c|c|c|c|c|c|c|c|c|c|c|c|c|}
\hline Variety & $\begin{array}{l}\text { Plant } \\
\text { height } \\
(\mathrm{cm})\end{array}$ & $\begin{array}{l}\text { Total tillers } \\
\text { hill }{ }^{-1} \text { (no.) }\end{array}$ & $\begin{array}{l}\text { Effective } \\
\text { tillers hill-1-1 } \\
\text { (no.) }\end{array}$ & $\begin{array}{c}\text { Non } \\
\text { effective } \\
\text { tillers hill-1 } \\
\text { (no.) } \\
\end{array}$ & $\begin{array}{l}\text { Panicle } \\
\text { length } \\
(\mathrm{cm})\end{array}$ & $\begin{array}{l}\text { Grain } \\
\text { panicle-1 }^{-1} \\
\text { (no.) }\end{array}$ & $\begin{array}{c}\text { Sterile } \\
\text { spikelet } \\
\text { panicle-1 }^{-1} \\
\text { (no.) } \\
\end{array}$ & $\begin{array}{c}1000 \text { grain } \\
\text { weight } \\
\text { (g) }\end{array}$ & $\begin{array}{l}\text { Grain } \\
\text { yield } \\
\text { (t/ha) }\end{array}$ & $\begin{array}{l}\text { Straw } \\
\text { yield } \\
\text { (t/ha) }\end{array}$ & $\begin{array}{l}\text { Biological } \\
\text { yield } \\
\text { (t/ha) }\end{array}$ & $\begin{array}{l}\mathrm{HI} \\
(\%)\end{array}$ \\
\hline $\mathrm{V}_{1} \mathrm{~T}_{1}$ & 137.6 & $14.2 \mathrm{c}$ & $10.4 \mathrm{C}$ & $3.8 \mathrm{c}$ & $24.97 \mathrm{bc}$ & $121.3 \mathrm{e}$ & $17.4 \mathrm{~g}$ & $3.31 \mathrm{ef}$ & $5.80 \mathrm{ab}$ & $25.92 \mathrm{a}$ & $9.11 \mathrm{c}$ & $36.37 \mathrm{c}$ \\
\hline$V_{1} T_{2}$ & 140.6 & $18.0 \mathrm{a}$ & $13.6 \mathrm{a}$ & $4.4 \mathrm{a}$ & $26.26 \mathrm{a}$ & $156.2 \mathrm{a}$ & $34.6 \mathrm{a}$ & $6.05 a$ & $6.00 \mathrm{a}$ & $26.37 \mathrm{a}$ & $12.05 \mathrm{a}$ & $50.24 a$ \\
\hline $\mathrm{V}_{1} \mathrm{~T}_{3}$ & 139.6 & $16.3 \mathrm{~b}$ & $12.4 \mathrm{~b}$ & $4.0 \mathrm{bc}$ & $25.48 \mathrm{ab}$ & $122.1 \mathrm{de}$ & $27.0 \mathrm{c}$ & $5.59 \mathrm{~b}$ & $5.91 \mathrm{a}$ & $26.10 \mathrm{a}$ & $11.49 \mathrm{a}$ & $48.56 \mathrm{ab}$ \\
\hline$V_{1} T_{4}$ & 139.0 & $17.8 \mathrm{a}$ & $13.2 \mathrm{ab}$ & $4.2 \mathrm{ab}$ & $25.72 a b$ & $140.9 \mathrm{~b}$ & $31.4 \mathrm{~b}$ & $5.57 \mathrm{~b}$ & $5.92 \mathrm{a}$ & $26.25 \mathrm{a}$ & $11.49 \mathrm{a}$ & $48.44 a b$ \\
\hline $\mathrm{V}_{2} \mathrm{~T}_{1}$ & 128.6 & $10.4 \mathrm{f}$ & $7.8 \mathrm{def}$ & $2.6 \mathrm{fg}$ & $21.8 \mathrm{e}$ & $128.0 \mathrm{~cd}$ & 20.1 ef & $3.51 \mathrm{ef}$ & $3.51 \mathrm{e}$ & $25.10 \mathrm{a}$ & $7.020 \mathrm{e}$ & $50.02 \mathrm{a}$ \\
\hline $\mathrm{V}_{2} \mathrm{~T}_{2}$ & 134.3 & $11.6 \mathrm{~d}$ & $8.6 \mathrm{~d}$ & $3.2 \mathrm{de}$ & 25.22ac & $146.0 \mathrm{~b}$ & $22.3 \mathrm{~d}$ & $5.38 \mathrm{~b}$ & $5.38 \mathrm{~b}$ & $25.32 a$ & $10.76 \mathrm{~b}$ & $50.00 \mathrm{a}$ \\
\hline $\mathrm{V}_{2} \mathrm{~T}_{3}$ & 130.3 & 10.6 ef & $8.0 \mathrm{def}$ & $2.2 \mathrm{~h}$ & $24.75 b c$ & $129.3 \mathrm{c}$ & $20.4 \mathrm{e}$ & $4.52 \mathrm{c}$ & $4.52 \mathrm{c}$ & $25.19 \mathrm{a}$ & $9.04 \quad c$ & $50.01 \mathrm{a}$ \\
\hline $\mathrm{V}_{2} \mathrm{~T}_{4}$ & 130.8 & $10.8 \mathrm{def}$ & $8.4 \mathrm{de}$ & $3.1 \mathrm{e}$ & $24.76 \mathrm{bc}$ & $132.0 \mathrm{C}$ & $22.4 \mathrm{~d}$ & $4.68 \mathrm{C}$ & $4.65 \mathrm{c}$ & $25.25 \mathrm{a}$ & $9.33 \mathrm{c}$ & $50.22 a$ \\
\hline $\mathrm{V}_{3} \mathrm{~T}_{1}$ & 107.9 & $9.4 \mathrm{~g}$ & $6.8 \mathrm{~g}$ & $2.4 \mathrm{gh}$ & $21.7 \mathrm{e}$ & $86.9 \mathrm{~h}$ & $10.1 \mathrm{i}$ & $3.20 \mathrm{f}$ & $3.81 \mathrm{de}$ & $20.10 \mathrm{~b}$ & $7.02 \mathrm{e}$ & $45.72 \mathrm{~b}$ \\
\hline $\mathrm{V}_{3} \mathrm{~T}_{2}$ & 111.4 & $11.4 \mathrm{de}$ & $8.2 \mathrm{de}$ & $3.4 \mathrm{~d}$ & $24.65 \mathrm{bc}$ & $111.0 \mathrm{f}$ & $19.0 \mathrm{f}$ & $3.97 \mathrm{~d}$ & $4.27 \mathrm{~cd}$ & $20.58 \mathrm{~b}$ & $8.24 \mathrm{~d}$ & $48.29 a b$ \\
\hline $\mathrm{V}_{3} \mathrm{~T}_{3}$ & 110.7 & $10.0 \mathrm{fg}$ & $7.2 \mathrm{fg}$ & $2.4 \mathrm{gh}$ & $23.10 \mathrm{~d}$ & $90.08 \mathrm{~h}$ & $12.8 \mathrm{~h}$ & $3.41 \mathrm{ef}$ & $3.99 \mathrm{de}$ & $20.23 \quad b$ & $7.40 \quad \mathrm{e}$ & $46.01 \mathrm{~b}$ \\
\hline $\mathrm{V}_{3} \mathrm{~T}_{4}$ & 109.3 & $10.4 \mathrm{f}$ & 7.6 efg & $2.8 \mathrm{f}$ & $24.00 \mathrm{~cd}$ & $98.6 \mathrm{~g}$ & $16.8 \mathrm{~g}$ & $3.58 \mathrm{e}$ & $3.89 \mathrm{de}$ & $20.17 \mathrm{~b}$ & $7.47 \mathrm{e}$ & $47.74 a b$ \\
\hline$s \bar{x}$ & 1.99 & 0.29 & 0.28 & 0.08 & 0.38 & 2.23 & 0.43 & 0.11 & 0.16 & - & 0.21 & 1.04 \\
\hline $\mathrm{LSD}_{0.05}$ & 5.74 & 0.84 & 0.81 & 0.25 & 1.10 & 6.42 & 1.25 & 0.32 & 0.46 & - & 0.60 & 2.99 \\
\hline $\begin{array}{c}\text { Level of } \\
\text { significance }\end{array}$ & NS & ** & ** & ** & * & ** & ** & ** & ** & NS & ** & ** \\
\hline CV\% & 3.15 & 4.67 & 6.04 & 5.57 & 3.15 & 3.66 & 4.10 & 5.16 & 6.70 & 3.73 & 4.58 & 4.37 \\
\hline
\end{tabular}

In a column figures with same letters do not differ significantly whereas figures with dissimilar letters differ significantly (as per DMRT). ${ }^{* *}=$ Significance at $1 \%$ level of probability, $\mathrm{T}_{1}=$ Traditional Urea by broadcasting method, $\mathrm{T}_{2}=$ Hand placement method of USG, $T_{3}=B A U$ USG applicator method, $T_{4}=B A R I$ USG applicator method, $V_{1}=B R 11, V_{2}=B R R I$ dhan $40, V_{3}=$ Pajam

\section{Conclusion}

From the discussions of the above stated results, it can be concluded that, BR11 performed the best regarding grain yield. But all the varieties have some advantages and disadvantages over one another. BRRI dhan40 matured later by 12 days compared to other two rice varieties. This may facilitate the accommodation of the succeeding crop in sequence. Therefore, any one of the varieties may be chosen depending on choice and performance of the farmers. Hand placement method of USG performed the best in respect of grain yield irrespective of varieties. These might be happened due to uniform placement of urea in the root zone in case of USG applicator due to blocking problem in discharge pipe USG pillets were not placed uniformly. Hence it can be recommended that farmers can use USG by hand placement method. But in terms of cost versus yield, machine placement also recommended as it reduces labor cost and time.

\section{References}

BADC (Bangladesh Agricultural Development Corporation). 2011. A leaflet of production technology for SL-8H rice Production. Hybrid seed production wing of BADC.

BARI (Bangladesh Agricultural Research Institute). 2011. A leaflet of Urea Super Granule Applicator. Farm Machinery Division, Bangladesh Agricultural Research Institute. Joydebpur, Gazipur, Bangladesh.

BBS (Bangladesh Bureau of Statistics). 2010. Statistical Year Book of Bangladesh Bureau of Statistics, Stat. Div., Minis. Plan., Govt. People's Repub. Bangladesh, Dhaka.127 p.

Bhowmick, N. and Nayak, R.L. 2000. Response of hybrid rice (Oryza sativa) varieties to nitrogen, phosphorus and potassium fertilizers during dry (boro) season in West Bengal. Indian J. Agron. 45(2): 323- 326.

Bhuiyan, N.L, Miah, M.A.M. and Ishaque, M. 1998. Research on USG: Findings and Future Research Areas and Recommendation. Paper presented at the National Workshop on USG technology, held at BARC Dhaka, Bangladesh, 25 June, 1998.

BINA (Bangladesh Institute of Nuclear Agriculture). 1998. Annual Report for 1997-98. Bangladesh Inst. Nucl. Agric. P. O. box No. 4, Mymensingh. p. 143.

Bowen, W.T., Diamand, R.B., Sing, U. And Thompson, T.P. 2005. Urea deep placement increases yield and saves N fertilizer in farmer's field in Bangladesh. Rice in life: Scientific Perspectives for the $21^{\text {st }}$ century. pp.369-372.

BRRI. 2011. AdunikDhanerChash(in Bengali).18th Edn. Bangladesh Rice Res. Inst., Joydebpur, Gazipur. pp. 17-30. 
Chowdhury, M.J.U., Sarker, A.U., Sarkar, M.S.R. and Kashem, M.A. 1993.Effect of variety and number of seedlings hill ${ }^{-1}$ on the yield and its components on late translanted aman rice. Bangladesh J. Agril. Sci. 20(2): 311-316.

De Datta, S.K. and Buresh, R.J. 1989.Integrated nitrogen management in irrigated rice. Adv. Soil Sci. 10: 143-169.

Gomez, K.N. and Gomez, A.A. 1984. Statistical procedures for agricultural research. John Wiley and Sons, New York, 2nd ed., pp 68.

Khisha, K. 2002. An evaluating of Madagascar system of rice production in aman season with three high potential rice varieties.MS Thesis, Dept. Agron., Bangladesh Agril, Univ., Mymensingh . 98 p.

Om, M.R. acid Desai, N.D. 1998. Sources and methods of N application for irrigated wetland rice. Intl. Rice Res. Newsl.12 (2):43.

Patel, S.R. 2000. Effect of different forms of urea and levels of nitrogen on the yield and nitrogen uptake of rice. Advan. PI. Sci. 7 (2): 297-401.

Rahman, M.A. 2003. Effect of urea super granules and depth of placement on the growth and yield of transplant aman rice. MS (Ag.) Thesis, Dept. Agron., Bangladesh Agril., Univ., Mymensingh. 100p.

Shamsuddin, A.M., Islam, M.A. and Hossain, A. 1988. Comparative study on the yield and agronomic characters of nine cultivars of aus rice. Bangladesh J. Agric. Sci.15 (1):121-124.

Singh, S. and Gangwer, B. 1989. Comparative studies on production potentials in traditional tall and improved rice cultivars. J. Andaman Sci. Assoc. 5 (1):81-82.

Strivastava, O.K. and Tripathi, R.S. 1998. Response of hybrid and composite rice to number of seedling and planting geometry. Ann. Agil. Res. Newsl. pp 235-236. 